\section{Subpoena Duces Tecum}

Robert L. Heilbronner

Chicago Neuropsychology Group, Chicago, IL, USA

\section{Definition}

A subpoena which requests items to be brought with the person to deposition or trial is called a "subpoena duces tecum." A subpoena is an order directed to an individual commanding him/her to appear at a deposition or in court on a certain day to testify or produce documents in a pending lawsuit. The power to subpoena a person is granted by officers of the court, such as clerks of courts, attorneys, and judges. A person may be subpoenaed to appear in court or any designated location to provide testimony for trial or deposition or produce documents or other evidence. Failure to comply with a subpoena may subject a person to being held in contempt of court if the absence appears to be intentional or without cause.

Melton et al. (2007) wrote that fear of a subpoena may cause some clinicians to keep only minimal information in their file or to create a separate "personal" file. Yet, merely labeling a file "personal" does not exclude the clinician from having to respond to the subpoena. If the judge learns about the hiding of such evidence, the clinician could be held in contempt. They suggest that the best approach is to keep complete files. Any information that is irrelevant can and should be excluded by the judge. Information that is relevant should not embarrass the examiner who has done an honest job.

\section{References and Readings}

Melton, G. B., Petrila, J., Poythress, N. G., \& Slobogin, C. (2007). Psychological evaluations for the courts: A handbook for mental health professionals and lawyers (3rd ed.). New York: Guilford Press. 